\title{
Miranda
}

Revue pluridisciplinaire du monde anglophone /

Multidisciplinary peer-reviewed journal on the English-

speaking world

$21 \mid 2020$

Modernism and the Obscene

\section{Hélène Ibata. The Challenge of the Sublime. From Burke's Philosophical Enquiry to British Romantic Art}

\section{Laurent Châtel}

\section{OpenEdition}

\section{Journals}

\section{Electronic version}

URL: http://journals.openedition.org/miranda/29927

DOI: $10.4000 /$ miranda.29927

ISSN: 2108-6559

Publisher

Université Toulouse - Jean Jaurès

\section{Electronic reference}

Laurent Châtel, "Hélène Ibata. The Challenge of the Sublime. From Burke's Philosophical Enquiry to British Romantic Art", Miranda [Online], 21 | 2020, Online since 13 October 2020, connection on 16 February 2021. URL: http://journals.openedition.org/miranda/29927 ; DOI: https://doi.org/10.4000/miranda. 29927

This text was automatically generated on 16 February 2021

\section{(c) $(1)$}

Miranda is licensed under a Creative Commons Attribution-NonCommercial-NoDerivatives 4.0 International License. 
Hélène Ibata. The Challenge of the Sublime. From Burke's Philosophical Enquiry to British Romantic Art

Laurent Châtel

\section{REFERENCES}

Hélène Ibata. The Challenge of the Sublime. From Burke's Philosophical Enquiry to British Romantic Art. Manchester University Press, 2018. ISBN : 1526117398

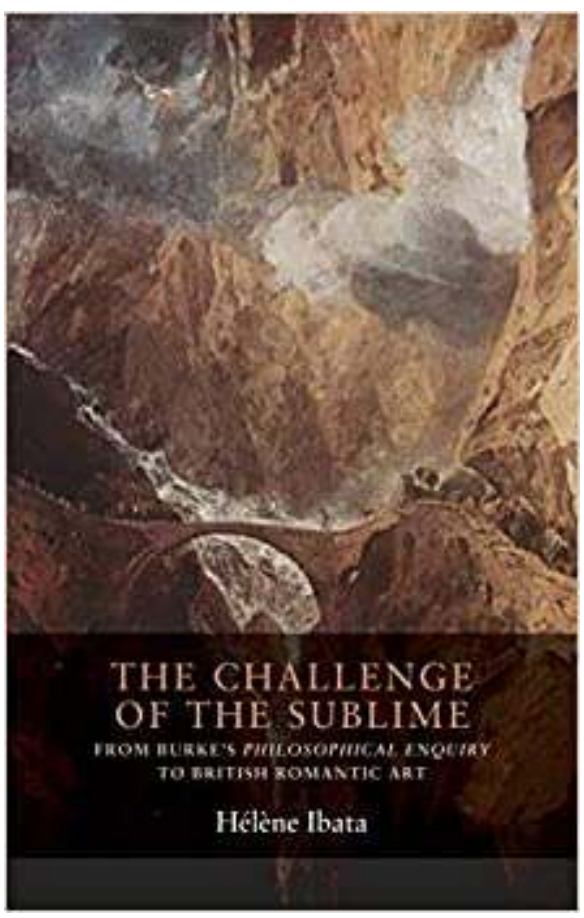


1 Edmund Burke's Philosophical Enquiry into the Origin of our Ideas of the Sublime and Beautiful (1757) is of one of the most well-known texts of eighteenth-century British art and aesthetics alongside with Hogarth's Analysis of Beauty (1753) and Reynolds's Discourses at the Royal Academy (1769 - 1790). But The Challenge of the Sublime by Hélène Ibata sheds new and fresh light on the Enquiry as it tackles Burke's reception and legacy among nineteenth-century British artist. Ibata contends that by implying painters could not rouse sublime feelings as much as poetry, Burke succeeded in provoking painters who became intent on proving him wrong. Just as poets had long been thought to induce sublime thoughts in their readers, painters equally felt there was no reason to check their flights of imagination and restrain their talent for representation on canvas. Ibata pushes her argument one step further: she suggests that the sublime became a (new) challenge for artists to take up in order to win over the technical constraints which they faced with two-dimensional canvasses and the age-old paradigm of mimesis. The "challenge of the sublime" also thus refers to artists' frustrations at Burke's underestimation of the powers of pictorial power and thus to Burke challenging artists into renewed creativity: he fueled artists with energy and ideas to experiment further with visual representation. The first part of the book is a survey of the genesis as well as the afterlife of Burke's Enquiry; first of all, a genealogy of sublime theories is provided, concerned with highlighting the various strands of thinking on the sublime that went into Burke's essay which is presented as the "culmination" of a long tradition with radical, subversive potential. The study of his relation to previous explorations of the sublime, notably Longinus Peri Hupsous, as well as his affinities with more recent British writers, highlights Burke's idiosyncratic and unique place, and his role in subverting and adapting it: Burnet, Dennis, Shaftesbury, Addison and Baillie are called up as possible sources and forerunners of Burke's ideas. The seeds of important aspects of his essay, its emphasis on terror and on the passions, its repertoire of natural sources of the sublime, and its pioneering "psychology" of the sublime can all be traced back to several layers of British thought. Secondly, the posterity of Burke's essay is examined particularly in relation to Sir Joshua Reynolds and James Barry, two early shapers of the Royal Academy of Arts. Chapter four highlights the fascinating double portrait by Barry of himself with his friend Burke in a striking and admittedly bewildering epic episode taken from Homer's Odyssey - Portraits of Barry and Burke in the Characters of Ulysses and a Companion Fleeing from the Cave of Polyphemus (Crawford Art Gallery, Cork); this image epitomizes the study conducted in Part I on the actual incidence and import of the intellectual connections and exchanges that shaped the Enquiry. The three chapters of part II of the book study the ways British artists challenged the constraining idea of "narrow limits of painting", focusing respectively on panoramic canvasses, frames and architectural fantasies. Ibata's central tenet is Burke's skepticism about the possibility of a pictorial sublime. Her main target is to gauge whether his ideas hindered or conversely exacerbated pictorial practices in reaction to academic exhibition paintings; she argues that the growing taste for the aesthetics of terror necessitated innovative means to counteract what was often deplored about painting on canvas at that time, the necessarily "quadrilateral frame of the painting" (p. 148). In this part the fashion for book illustration and beyond-theframe panoramas are studied very closely as visual supplements and tools to transcend pictorial finiteness. The last two chapters of the book (Part III) focus on Blake and Turner's interpretations of the sublime. While seeing Burke in the context of his contemporary readers, contacts and friendships, such as painters Reynolds and Barry, 
the book is also shaped by later philosophical and art historical readings of the sublime, notably those of Immanuel Kant, Louis Marin, Jean-Luc Nancy, and Jacques Derrida: their definitions and interpretations are made to reverberate back onto Burke- a nonhistoricist posture which enables a widening of the acceptation (and expectations) of the late eighteenth-century sublime, but somehow stretches Burke beyond his intent and design. As a whole, the book provides the most comprehensive study to date of the interrelation between a well-established text (too often read in isolation in past writings) and manifold British pictorial practices conceived here as more or less direct reactions to Burke's ideas and beliefs. As such, needless to say Hélène Ibata's book is of utmost interest to students and scholars alike of nineteenth-century art and aesthetics.

It is one of the greatest merits of the book to trigger off questions which open up a forum for discussion and a renewed consideration of what, for the nineteenth century, characterizes the artistic achievements of British painting and what constitutes the experience of the sublime. Firstly, one may wonder whether the contention that Burke was going "against the whole tradition of the sister arts" is a case of Burke "dividing" the arts or rather simply reinforcing the hierarchy between them in favour of poetry? For that matter, when it comes to ut pictura poesis, the book contains a stimulating invitation to rethink the full extent of the incidence and dialogue between the theories of Bodmer, Burke and Lessing. Secondly, one is left wondering how to interpret Burke's presumed anti-pictorialism. Baldine Saint Girons put it down to his anchorage in rhetoric and belles lettres, and his own specific interest in the performativity of speech and power. As Burke himself put it, he was "without any affectation, thoroughly convinced, that he ha ( $\mathrm{d}$ (no skill whatsoever in the art of painting" (Letter to Barry, p. 122). Therefore it is delicate to infer from his friendship with artists that that there was anything in him to think things out visually. What with being still very young and mainly steeped in literary culture, Burke was ill-fitted in the 1750 s for contemplating the (future) potential of British art (despite his acquaintance with artists) and he just did not envisage the awe-inspiring effect and intensity of affect of canvasses. Similarly, it is difficult to infer from Burke's emphasis on drawing and determinacy, which he ranked as being essential training of great artists, that he was excluding painting altogether from any qualification for sublimity-was Blake after all not taking up the cudgels both for linearity, determinacy and the quest of the sublime? One is also left wondering whether the idea that Burke 'draws attention to the visual arts as the locus of a representational crisis' is over-exaggerated; for all his fears that painting may be too imitative and fail to rise above mechanical crafts, Burke would hardly have been bent on exploring the present or/and future state of visual arts. This makes one think of Horace Walpole in his Anecdotes of Painting (1762-80) explicitly calling for a school of landscape in Britain (on account of the fine countryside which was readily available to inspire British artists) as if Britain had not already been producing landscape painting. Difficult to say whether Walpole was blind to them or simply being provocative and controversial. As for Burke, it is more convincingly a case of being dedicated to classical learning and belles lettres. Finally, one may take issue with the working hypothesis throughout that the sublime should not be thought beyond representation. This brings to the fore two questions - firstly it is worth asking whether Burke's paramount concern was reception rather than representation as testified by his focus on the perceptions of readers and spectators."It is a different matter altogether to assess the sublime from the point of view of representation: could painters not paint sublime objects and settings with sublime textures and handling without, in the end, viewers 
necessarily being seized with the sublime? How does viewing Turner's Dolbadern Castle compare with viewing Dolbadarn itself on the Welsh Marches? Secondly, one may ask whether the sublime as a psycho-aesthetic category of art appreciation should not remain an intermediate experience that is always characterized by being 'below the limit', on the edge, in suspension and in-between? The sublime partakes of divinity and transcendence-whichever it might be-, so it is perhaps worth suggesting that when men and women have a share in it, they always see and feel it from below, beyond any representational frame and artefact. This makes one think of Whately declaring in his Observations on Modern Gardening (1770) that gardening is superior to landscape painting, as a reality to representation. For the sake of intensity, the sublime needs to be a direct experience in the flesh - non-virtual, non-vicarious, devoid of proxy, but not fully 'bodied'.

INDEX

Keywords: art, aesthetics, British visual arts, sublime, landscape, mimesis, sister arts, reception studies, representation, word and image

Mots-clés: art, esthétique, arts visuels britanniques, sublime, paysage, mimesis, arts sœurs, études de la réception, représentation, texte et image

\section{AUTHORS}

\section{LAURENT CHÂTEL}

Professeur des universités Université de Lille

laurent.chatel@univ-lille.fr 